\title{
Peranan Dinas Tenaga Kerja Kota Medan Memberikan Perlindungan Hukum Dalam Perjanjian Kerja Bagi Pekerja Outsourcing
}

\author{
Oleh Soraya Fadillah \\ sorayafadillah25@yahoo.com \\ Mahasiswa Magister Hukum Pascasarjana UNPAB
}

\begin{abstract}
Abstrak
Penelitian ini membahas tentang Peranan Dinas Tenaga Kerja Kota Medan Memberikan Perlindungan Hukum Dalam Perjanjian Kerja Bagi Pekerja Outsourcing. Metode penelitian yang digunakan yuridis empiris dengan meneliti peranan pengawasan Dinas Tenaga Kerja Kota Medan dalam memberikan perlindungan bagi pekerja outsourcing di Medan. Perlindungan hukum terhadap pekerja dalam perjanjian kerja dengan sistem outsourcing Bahwa perlindungan hukum terhadap pekerja dalam perjanjian kerja dengan sistem outsourcing di Indonesia menggunakan ketentuan Pasal 64 s.d 65 dalam Undang-Undang No. 13 Tahun 2003 Tentang Ketenagakerjaan, Putusan Mahkamah Konsitusi dan Permenaker No. 19 Tahun 2012 Tentang Tentang Syarat-syarat Penyerahan Sebagian Pelaksanaan Pekerjaan Kepada Perusahaan Lain. Akan tetapi penyebutan nama outsourcing tidak pernah ada dalam ketentuan dalam Undang- Undang Ketenagakerjaan di Indonesia yang ada pemborangan dan penyerahan sebagaian pelaksanaan pekerjaan kepada perusahaan lain. Istilah outsourcing atau ahli daya hanya ada pada Inpres No. 3 Tahun 2006 tentang Paket Kebijakan Iklim investasi. Putusan Mahkamah Kositusi Nomor 27/PUU-X/2011 bahwa tetap menjadi tanggung jawab perusahaan yang memberi pekerjaan. Bahwa semenjak adanya Peraturan tentang Pemerintahan Daerah UndangUndang No. 23 Tahun 2014 tentang Pemerintah Daerah sebagaimana telah dirubah dengan Undang- Undang No. 9 Tahun 2015 tentang Pemerintah Daerah bahwa mengubah urusan pengawasan ketenagakerjaan yang awalnya berada di setiap tingkatan daerah menjadi hanya urusan Pemerintah Pusat dan Provinsi. Kondisi demikian berdampak pada penyelenggaraan pengawasan ketenagakerjaan yang semula berada di provinsi, kabupaten/ kota. Saran pengaturan tentang outsourcing harusnya dibuat secara jelas dan memberikan perlindungan bagi pekerja dan pengusaha melalui Pengesahan Rancangan Undang-Undang Ketenagakerjaan yang , namun sebaiknya outsourcing tidak harus ada dalam sistem Ketenagakerjaan di Indonesia karena merugikan pekerja. Bahwa Peranan Dinas Tenagakerja Kota Medan adanya peningkatan kemampuan dengan aktif, jeli, kritis dalam merespon laporan dan mengeluarkan bukti lapor yang harus memeriksa kesesuaian laporan Perusahaan pemberi pekerjaan adanya setiap perubahan jenis pekerjaan penunjang yang akan diserahkan melalui pemborongan pekerjaan, kepada instansi yang bertanggung jawab di bidang ketenagakerjaan kabupaten/kota tempat pemborongan pekerjaan dilaksanakan dengan tetap memperhatikan proses.
\end{abstract}

Kata kunci: Peranan Dinas, Perjanjian Kerja, Pekerja, Outsourcing 


\section{Pendahuluan}

Sistem outsourcing biasanya menggunakan perjanjian kerja waktu tidak tertentu lebih rendah dari pada ketentuan dalam peraturan Ketenagakerjaan di Indonesia, Peraturan Perusahaan, Perjanjian Kerja Bersama. Sistem outsourcing pada perakteknya menggunakan perjanjian kerja waktu tertentu melakukan pelanggaran atas ketentuan syaratdalam pembuatan Perjanjian Kerja Waktu Tertentu karena jenis dan sifat pekerjaan yang diberikan merupakan pekerjaan tetap yang terus menerus dan merupakan alur produksi, atau dalam praktek perjanjian kerja waktu tertentu dilaksanakan di sektor industri.

Pada tahun 2011 adanya Putusan Mahkamah Kositusi Nomor 27/PUU-X/2011 bahwa putusan ini menyatakan perjanjian kerja tidak disyaratkan adanya pengalihan perlindungan hakhak pekerja yang objeknya kerjanya tetap ada, walaupun terjadi pergantian perusahaan yang melaksanakan melalui sistem pemborangan dengan menggunakan pihak ketiga tetap berada pada perusahaan yang memberikan pekerjaan.

Penyedia jasa pekerja/ buruh untuk kegiatan jasa penunjang atau kegiatan yang tidak berhubungan langsung dengan proses produksi harus memenuhi syarat sebagaimana diatur di dalam Pasal 66 ayat $2 b$.

$$
\text { Berdasarkan }
$$

Keputusan Mahkamah
Konsitusi istilah Perjanjian Kerja Waktu Tidak Tertentu tidak dapat dimuat pada pasal 65 ayat (7) dan pada pasal 66 ayat (2) b dengan kata lain outsourcing tidak berlaku lagi pada pekerjaan apapun, kecuali memenuhi kreteria pada pasal 59 tentang Perjanjian Kerja waktu tidak tertentu. Sehingga pekerjaan cleaning service, accounting, admin asistant atau sekretaris tidak dapat lagi dioutsourcing menjadi pekerjaan waktu tidak tetap sebab bukan pekerjaan musiman dan sementara.

Pelaksanaan

outsourcing melibatkan 3 (tiga) pihak yakni perusahaan penyedia tenaga kerja outsourcing, perusahaan pengguna tenaga kerja outsourcing, dan tenaga kerja outsourcing itu sendiri. Oleh karena itu perlu adanya suatu peraturan agar pihak-pihak yang terlibat tidak ada yang dirugikan khususnya tenaga kerja outsourcing.

Dinas Tenaga Kerja Kota/Kabupaten harus sudah menerbitkan ijin operasional terhadap permohonan yang telah memenuhi ketentuan diatas dalam waktu paling lama 30 hari sejak permohonan diterima. Ijin operasional bagi perusahaan penyedia tenaga kerja berlaku diseluruh Indonesia untuk jangka waktu 5 tahun dan dapat diperpanjang untuk jangka waktu yang sama. 
Namun putusan Mahkamah Konstitusi No. 27/PUU-IX/2011, menyatakan bahwa ada model yang harus dipenuhi dalam perjanjian kerja outsourcing yaitu Pertama, dengan mensyaratkan agar perjanjian kerja antara pekerja dan perusahaan yang melaksanakan

pekerjaan outsourcing tidak berbentuk perjanjian kerja waktu tertentu ("PKWT"), tetapi berbentuk perjanjian kerja waktu tidak tertentu ("PKWTT"). Kedua, menerapkan prinsip pengalihan tindakan perlindungan bagi pekerja yang bekerja pada perusahaan yang melaksanakan pekerjaan outsourcing.

Putusan Mahkamah Konstitusi ini menyiratkan bahwa setiap pekerja outsourcing terjamin kedudukannya dalam perusahaan pengguna karena perjanjian kerjanya bersifat PKWTT atau tetap.

Dengan adanya ketentuan ini bahwa segala kegiatan otsourcing harus dilaporkan ke Dinas Tenagakerja Kerja di tingkat Kabupaten/Kota. Sehingga untuk Kota Medan bahwa Dinas Ketenagakerjaan Kota Medan menerima laporan dan mengeluarkan bukti laporan outsourcing. Terkait dengan aparatur dalam menjamin perlindungan

Ketenagakerjaan di Kota Medan dilakukan oleh Dinas
Ketenagakerjaan Kota

Medan. Berdasarkan

Peraturan Daerah Kota Medan

Nomor 15 Tahun 2016

Tentang Pembentukan

Perangkat Daerah Pada

Pemerintah Kota Medan dan

Peraturan Walikota Medan

Nomor 62 Tahun 2017 tentang

Rincian Tugas dan Fungsi

Dinas

Ketenagakerjaan Kota Medan maka Dinas Ketenagakerjaan

Kota Medan mempunyai tugas melaksanakan kewenangan desentralisasi dibidang tenaga kerja dan tugas lainnya yang diberikan Kepala Daerah. Dalam menyelenggarakan tugas tersebut di atas, Dinas Ketenagakerjaan Kota Medan mempunyai fungsi - fungsi, sebagai berikut:

1. Perumusan kebijakan teknis di bidang ketenagakerjaan;

2. Penyelenggaraan urusan pemerintahan dan pelayanan umum di bidang ketenagakerjaan;

3. Pembinaan dan pelaksanaan tugas di bidang ketenagakerjaan; dan

4. Pelaksanaan tugas lain yang diberikan olehWalikota sesuai dengan tugas dan fungsinya.

Berdasarkan tugas pokok dan fungsi Dinas Ketenagakerjaan Kota Medan tidak terkait pada pengawasan ketenagakerjaan, fungsi ini berada pada Dinas Ketenagakerjaan Provinsi Sumatera Utara yang 
memiliki kewenangan dalam melakukan pengawasan Ketenagakerjaan Di Sumatera Utara. Dengan dibatasinya perana Dinas Ketenagakerjaan Kota Medan hanya dalam hal pertama perumusan kebijakan teknis di

bidang ketenagakerjaan; kedua penyelenggaraan urusan pemerintahan dan pelayanan umum di bidang ketenagakerjaan; pembinaan dan pelaksanaan tugas di bidang ketenagakerjaan; dan pelaksanaan tugas lain yang diberikan oleh Walikota sesuai dengan tugas dan fungsinya artinya mereka tidak memiliki fungsi sebagai pengawas hanya membina artinya proses pembinaan terhadap pengusaha dan pekerja dapat dilakukan oleh Dinas Ketenagakerjan Kota Medan. Sehingga hal ini menjadi kajian yang sangat menarik untuk diteliti tentang peranan Dinas Ketenagakerjaan Kota Medan dalam membina sistem outsourcing. Berdasarkan penjelasan di atas, maka peneliti membatasi judul tentang Peranan Dinas Tenaga Kerja Kota Medan Memberikan Perlindungan Hukum Dalam Perjanjian

Kerja Bagi Pekerja Outsourcing.

\section{Metode Penelitian}

Metode penelitian menggunakan yuridis empiris dengan meneliti permasalahan tetang peranan
Dinas Tenagakerja Kota Medan dalam mengawasi perjanjia kerja dengan pekerja outsourcing di Medan.

\section{Bagan 1.1 Skema Proses Penelitian Yuridis Empris}

Pengumpulan Data primer dari studi kasus dan wawancara. Data sekuder melalui studi pustaka.

Data yang diperoleh dilakukan pengorganisasian diseleksi dan disusun secara sistematis.

Analisis Data menggunakan deskriptif kualitatif

Ditarik Kesimpulan sebagai jawaban atas permasalahan yang diteliti dengan metode induktif yaitu suatu proses penalaran yang berangkat dari suatu kalimat pernyataan khusus untuk tiba pada suatu simpulan yang akan dapat menjawab suatu pernyataan yang bersifat umum.

\section{Hasil Penelitian dan Pembahasan}

Dalam memberikan perlindungan kepada pekerja dengan sistem outsourcing di Medan menggunakan 
ketentuan sebagaimana yang diatur di dalam UndangUndang No. 13 Tahun 2003

Tentang Ketenagakerjan Peraturan Menteri

Ketenagakerjaan RI No. 19 Tahun 2012 Tentang Syaratsyarat Penyerahan Sebagian Pelaksanaan Pekerjaan Kepada Perusahaan Lain, sesuai dengan tugas pokok dan fungsi Dinas Sosial Tenaga Kerja sebagaimana yang diatur pada Peraturan Daerah Kota Medan Nomor 15 Tahun 2016 Tentang Pembentukan Perangkat Daerah Pada Pemerintah Kota Medan dan Peraturan Walikota Medan Nomor 62 Tahun 2017 tentang Rincian Tugas dan Fungsi Dinas Ketenagakerjaan Kota Medan, maka Dinas Ketenagakerjaan Kota Medan mempunyai tugas melaksanakan kewenangan desentralisasi dibidang tenaga kerja dan tugas lainnya yang diberikan Kepala Daerah. Ketentuan ini menjadi dasar dalam memberikan perlindungan hukum kepada pekerja dengan sistem outsourcing.

Menganalisis kondisi sistem hukum yang baik terdiri dari adanya peraturan hukum yang berlaku, bagaimana aparatur hukum dalam menjalankan aturan hukum yang berlaku terakhir adanya budaya hukum di masyarakat dalam melaksanakan hukum yang belaku, sehingga terbentuk sistem hukum yang baik bertujuan untuk memberikan kepastian hukum, keadilan dan kemanfaatan bagi seluruh pihak. Jika dikaji dalam peranan Dinas Sosial dan Tenaga Kerja Kota Medan berfungsi dalam memberikan kepastian hukum, keadilan dan kemanfaatan bagi pekerja dengan sistem outsourcing khususnya di Kota Medan.

Dalam melaksanakan fungsinya Dinas Sosial dan Tenaga Kerja Kota Medan mengalami kendala internal yang berada pada organisasi yang ada di dinas hal terjadi diakibatkan pertama dari jumlah personil yang ada tidak memadai dalam memberikan pelayanan, pembinaan kepada pekerja outsourcing, kedua menjalankan tupoksi terbatas karena pengawasan tenaga kerja dilakukan oleh provinsi, ketiga selain itu yang

mengeluarkan izin operasional perusahaan outsourcing adalah provinsi, keempat dalam pasal 6 menyebutkan bahwa Instansi yang bertanggung jawab di bidang ketenagakerjaan adalah kabupaten/kota sebagaimana dimaksud dalam Pasal 5 mengeluarkan bukti pelaporan jenis pekerjaan penunjang yang akan diserahkan melalui pemborongan pekerjaan paling lambat 1 (satu) minggu sejak pelaporan 
dilaksanakan oleh perusahaan pemberi pekerjaan, hanya sebatas proses pelaporan meskipun dalam praktek banyak perusahaan dengan sistem outsourcing tidak melaporkan sebagaimana yang diatur di dalam Pasal 6 Peraturan Menteri Tenaga Kerja No. 19 tahun 2012 Tentang Tentang Syaratsyarat Penyerahan Sebagian Pelaksanaan Pekerjaan Kepada Perusahaan Lain, kelima pembinaan pekerja outsourcing tidak diatur di dalam ketentuan Permenaker, namun diatur di dalam visi misi Dinas Sosial dan Tenaga Kerja Kota Medan dan Peraturan Daerah Kota Medan hal ini yang menjadi dasar meskipun tidak diatur secara khusus untuk pekerja dengan sistem outsourcing bagi seluruh tenaga kerja dalam memberikan perlindungan bagi pekerja, keenam kurangnya kesadaran dan pemahaman aparatur dalam menjalankan tugas pokok dan fungsinya dalam memberikan perlundungan hukum bagi pekerja dengan sistem outsourcing di Kota Medan.

Berdasarkan hasil wawancara dengan Mediator Dinas Tenagakerja Kota Medan diperoleh data bahwa hubungan kerja pekerja dengan sistem outsourcing diatur di dalam UndangUndang No. 13 Tahun 2003 Tentang Ketenagakerjaan.
Hubungan kerja dengan perjanjian kerja sistem outsourcing menggunakan Perjanjian Kerja Waktu Tertentu wajib dicatatkan ke Dinas Tenagakerja Kota Medan. Dilakukan pada pengaduan yang masuk ke Dinas Tenagakerja Kota Medan.

\begin{tabular}{cc}
\multicolumn{2}{c}{ Kendala yang } \\
dihadapi dalam proses
\end{tabular} pengawasan ketenagakerjaan khusus hubungan kerja dosen dengan yayasan dikarenakan jumlah aparatur karena jumlah perusahaan yang harus diawasi tidak sebanding, sehingga tidak perlu diawasi jika tidak ada masalah. Tergantung pada pengaduan karena apabila tidak ada pengaduan berarti tidak ada permasalahan hukum yang terjadi. Tergantung pada

perusahaan dan pekerja yang melaporkan, apabila terjadi sengketa dengan pekerja dan pengusaha 1 bulan harus ada produk/putusan yang keluar. Perjanjian Kerja Waktu Tertentu (PKWT) dilaporkan ke Dinas Tenagakerja Kota Medan, tapi apabila tidak dilaporkan tidak ada sanksi tergantung apabila ada masalah saja diketahui oleh dinas. PKWT tidak dilaporkan tidak dibuat secara tertulis,

maka berubah menjadi Perjanjian Kerja Waktu Tidak Tertentu. Sehingga perjanjian kerja berubah statusnya dari tidak 
tetap menjadi pekerja tetap sebagaimana yang diatur dalam undang-undang ketenagakerjaan.

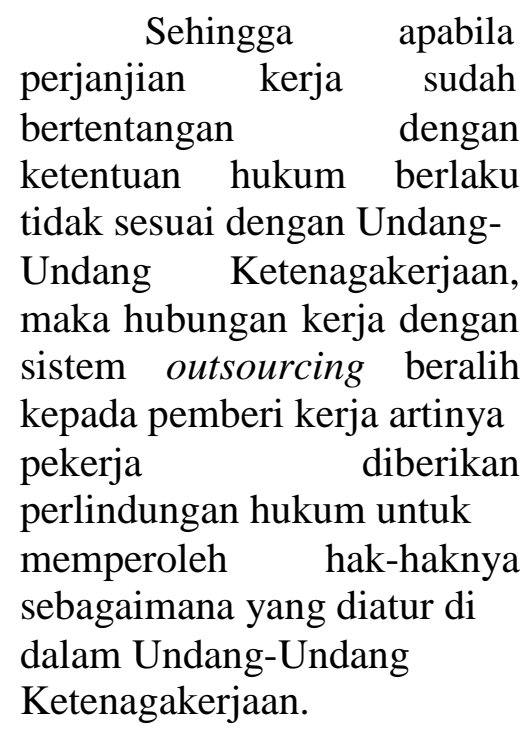

Selain itu adalah berdasarkan ketentuan perundang-undangan khusunya pasal 10 ayat (2) Undang-Undang Pemerintah Daerah bahwa menyelenggarakan urusan pemerintah absolut pemerinta pusat dapat melaksanakan sendiri atau melimpahkan kewenangannya kepada instansi vertikal yang ada didaerah atau gubernur sebagai wakil Pemerintah Pusat berdasarkan asas dekonsentrasi. Instansi vertikal adalah perangkat kementerian mengurus pemerintahan non kementerian yang mengurus urusan pemerintah yang tidak diserahkan kepada daerah otonomi dalam wilayah

tertentu dalam rangka dekonsentrasi. Dekonsentrasi adalah pelimpihan sebagaian kewenangan dari Pemerintah Pusat kepada gubernur dan bupati/walikota sebagai penangung jawab pada urusan pemerintahan umum.

Pelaksanaan

pengawasan dengan melandasakan kepada asas dekonsetrasi ketidaksesuaian pemerintah dalam penyelenggaraan pengawasan ketenagakerjaan. Pada tahun 2017 melalui Peraturaan

Menteri No. 20 tahun 2017

Tentang Pelaksanaan

Dekonsentrasi tahun anggaran 2018 berdasarkan hasil rekapitulasi alokasi anggaran per Provinsi sebesar Rp. 2,7 Milyar jika dilihat dari Sumatera Utara yang jumlah daerahnya sangat luasnya dan kabupaten/kota yang banyak, sehingga pengawasan terhadap kasus ketenagakerjaan di Sumatera Utara tidak dapat tertangani dengan baik. Hal ini juga disebabkan sedikitnya pengawasan ketenagakerjaan yang ada di Sumatera Utara, sehingga untuk mengawasi pelaksanaan outsourcing atau ahli daya tidak dapat terlaksana dengan baik.

\section{Simpulan}

Berdasarkan

penjelasan di atas sebagai berikut:

\section{Kesimpulan}

1.1 Perlindungan hukum terhadap pekerja dalam perjanjian kerja dengan sistem outsourcing Bahwa perlindungan 


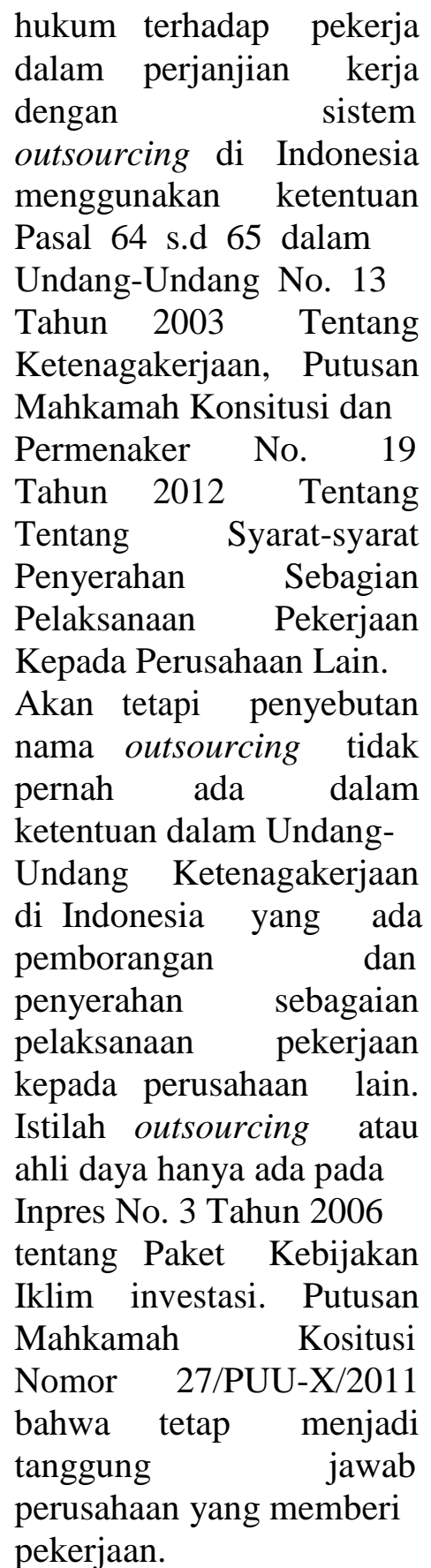

1.2 Bahwa semenjak adanya

Peraturan tentang

Pemerintahan Daerah

Undang-Undang No. 23

Tahun 2014 tentang

Pemerintah Daerah

sebagaimana telah

dirubah dengan Undang-

Undang No. 9 Tahun
2015 tentang Pemerintah

Daerah bahwa mengubah urusan pengawasan ketenagakerjaan yang awalnya berada di setiap tingkatan daerah menjadi hanya urusan Pemerintah Pusat dan Provinsi. Kondisi demikian berdampak pada penyelenggaraan pengawasan ketenagakerjaan yang semula berada di provinsi, kabupaten/ kta kemudian kembali ke provinsi. Akibat otonomi daerah menjadi kendala dalam pengawasan ketenagakerjaan di daerah khususnya di kabupaten/kota. Hal ini menyebabkan Pemerintah Pusat membuat kebijakan bahwa penetapan sistem pengawasan

ketenagakerjaan dan pengelolaan tenaga pengawas

ketenagakerjaan menjadi urusan Pemerintah Pusat, sedangkan kewenangan penyelenggaraan pengawasan ketenagakerjaan menjadi urusan Pemerintah Daerah Provinsi. Peranan Dinas Ketenagakerjaan Kota Medan dalam memberikan perlindungan hukum bagi pekerja outsourcing di Medan adalah berdasarkan ketentuan Peraturan Ketenagakerjaan di Indonesia baik Undang- 
Undang Ketenagakerjaan, Permenaker No. 19 Tahun 2012 Tentang Tentang Syarat-syarat Penyerahan Sebagian Pelaksanaan Pekerjaan Kepada Perusahaan Lain menerima laporan Dalam ketentuan pasal 5 Jenis pekerjaan penunjang yang akan diserahkan kepada perusahaan penerima pemborongan harus dilaporkan oleh perusahaan pemberi pekerjaan kepada instansi yang bertanggung jawab di bidang ketenagakerjaan kabupaten/kota tempat pemborongan pekerjaan dilaksanakan. Kebijakan dalam Peraturan Menteri Ketanagakerjaan pada pasal 6 menyebutkan Instansi yang bertanggung jawab di bidang ketenagakerjaan kabupaten/kota

sebagaimana dimaksud dalam Pasal 5 mengeluarkan bukti pelaporan jenis pekerjaan penunjang yang akan diserahkan melalui pemborongan pekerjaan paling lambat 1 (satu) minggu sejak pelaporan dilaksanakan oleh perusahaan pemberi

2. Saran pekerjaan.

\subsection{Bahwa} tentang harusnya dibuat secara jelas dan memberikan perlindungan bagi pekerja

\begin{abstract}
dan pengusaha melalui Pengesahan Rancangan Undang-Undang

Ketenagakerjaan yang, namun sebaiknya outsourcing tidak harus ada dalam sistem Ketenagakerjaan di Indonesia karena merugikan pekerja.

2.2 Bahwa Peranan Dinas Tenagakerja Kota Medan adanya peningkatan kemampuan dengan aktif, jeli, kritis dalam merespon laporan dan mengeluarkan bukti lapor yang harus

memeriksa kesesuaian laporan

Perusahaan pemberi pekerjaan adanya setiap perubahan jenis pekerjaan penunjang yang akan diserahkan melalui pemborongan pekerjaan, kepada instansi yang bertanggung jawab di bidang ketenagakerjaan kabupaten/kota tempat pemborongan pekerjaan dilaksanakan dengan tetap memperhatikan proses.
\end{abstract}

Daftar Pustaka Abdussalam H. R dan Adri Desasfuryanto, 2016, Hukum Ketenagakerjaan (Hukum Perburuhan), PTIK, Jakarta Husni. Lalu, 2015, Pengantar Hukum

Ketenagakerjaan, RajaGrafindo Persada, Jakarta.

Syamsuddin. Syaufii, 2003, Perjanjian-Perjanjian Dalam Hubungan Industrial, Sarana Bhakti Persada, Jakarta. 
Uwiyono. Aloysius, Siti. Hajati Hoesin, Widodo Suryandono, dan Melania Kiswandari, Asas-Asas Hukum Perburuhan, RajaGrafindo Persada, Jakarta.

\section{Peraturan Perundang-Undangan}

KUHPerdata terjemahan Prof. R Subekti, SH dan R. Tjitrosudibio, B.W. (Kitab Undang-Undang Hukum Perdata), Staatsblad 1847 No. 23. Undang-Undang No. 13 Tahun 2003 Tentang Ketenagakerjaan Lembaran Negara Republik Indonesia Tahun 2003 Nomor 39. 